\title{
Rancang Bangun Aplikasi Location Based Service untuk Informasi dan Pencarian Lokal Pasien Covid-19 Berbasis Sensor IMU (Inertial Measured Unit)
}

\author{
Dody Susilo*1, Lintank Dewi Prameswari ${ }^{2}$, Very Andika Putra ${ }^{3}$ \\ ${ }^{1,2,3}$ Universitas PGRI Madiun, Indonesia, Fakultas Teknik, Prodi Teknik Elektro \\ e-mail: *1 susilodody@unipma.ac.id, ${ }^{2}$ lintankdewi184@gmail.com, \\ ${ }^{3}$ quenkroc@gmail.com
}

\begin{abstract}
Abstrak
Penyakit virus Corona 2019 (Coronavirus Disease/Covid-19) merupakan nama baru yang diberikan oleh Wolrd Health Organization (WHO) bagi pasien dengan infeksi virus Covid-19 yang pertama kali dilaporkan dari kota Wuhan, Cina pada akhir 2019. Informasi mengenai Covid-19 dan penyebarannya dapat diketahui secara cepat dan akurat dengan memanfaatkan perkembangan ilmu pengetahuan dan teknologi. IMU (Inertial Measurement Unit) sangat berguna pada sistem navigasi dan kendali. IMU yang terdiri dari enam derajat kebebasan tersusun dari tiga sensor Accelerometer dan tiga sensor Gyroscope yang masing - masing ditempatkan pada tiga sumbu ( $x, y$, dan $z)$ dan saling tegak lurus. Penelitian ini memberikan solusi lain yaitu informasi dalam bentuk aplikasi perangkat bergerak berbasis android. Pada aplikasi ini terdapat fitur untuk memonitoring informasi mengenai penyebaran pasien coronavirus. Berdasarkan hasil penelitian menunjukkan bahwa Sensor IMU dapat bekerja dengan baik dan dapat menampilkan hasil Accelerometer dan Gyroscope.
\end{abstract}

Kata kunci-Bluetooth HC-05, Covid-19, IMU, Mikrokontroler, Smartphone

\begin{abstract}
Coronavirus Disease / Covid-19 is a new name given by the World Health Organization (WHO) for patients with Covid-19 virus infection which was first reported from the city of Wuhan, China at the end of 2019. Information about Covid-19 and its dissemination can be known quickly and accurately by taking advantage of developments in science and technology. IMU (Inertial Measurement Unit) is very useful in navigation and control systems. IMU which consists of six degrees of freedom composed of three Accelerometer sensors and three Gyroscope sensors, each of which is placed on three axes $(x, y$, and $z)$ and perpendicular to each other. This study provides another solution, namely information in the form of an Androidbased mobile application. In this application there is a feature to monitor information about the spread of coronavirus patients. Based on the research results, it shows that the IMU sensor can work well and can display the results of the Accelerometer and Gyroscope.
\end{abstract}

Keywords-Bluetooth HC-05, Covid-19, IMU, Microcontroller, Smartphone 


\section{PENDAHULUAN}

Di awal tahun 2020 ini, dunia dikagetkan dengan kejadian infeksi berat dengan penyebab yang belum diketahui, yang berawal dari laporan dari Cina kepada World Health Organization (WHO) terdapatnya 44 pasien pneumonia yang berat di suatu wilayah yaitu Kota Wuhan, Provinsi Hubei, China, tepatnya di hari terakhir tahun 2019 Cina. Dugaan awal hal ini terkait dengan pasar basah yang menjual ikan, hewan laut dan berbagai hewan lain. Pada 10 Januari 2020 penyebabnya mulai teridentifikasi dan didapatkan kode genetiknya yaitu virus corona baru.

Informasi tentang virus ini tentunya masih sangat terbatas karena banyak hal masih dalam penelitian dan data epidemiologi akan sangat berkembang juga, untuk itu tinjauan ini merupakan tinjauan berdasarkan informasi terbatas yang dirangkum dengan tujuan untuk memberi informasi dan sangat mungkin akan terdapat perubahan kebijakan dan hal terkait lainnya sesuai perkembangan hasil penelitian, data epidemiologi dan kemajuan diagnosis dan terapi [1].

Pada penelitian sebelumnya tentang "Rancang Bangun Sistem Fall Detection Untuk Orang Lanjut Usia Berbasis Inertial Measurement Unit" [2], pada penelitian ini dibuat aplikasi Location Based Service pasien Covid-19 menggunakan android ini dirancang dan dibangun. Perancangan aplikasi ini akan menampilkan koordinat lokasi pasien Covid-19 yang dicari. Dengan adanya aplikasi Location Based Service pasien Covid-19 pada android maka diharapkan dapat memenuhi kebutuhan informasi pasien Covid-19.

\section{METODE PENELITIAN}

\subsection{Coronavirus Disease (Covid-19)}

Di awal tahun 2020 ini, dunia dikagetkan dengan kejadian infeksi berat dengan penyebab yang belum diketahui, yang berawal dari laporan dari Cina kepada World Health Organization (WHO) terdapatnya 44 pasien pneumonia yang berat di suatu wilayah yaitu kota Wuhan, provinsi Hubei, China, tepatnya di hari terakhir tahun 2019 Cina. Dugaan awal hal ini terkait dengan pasar basah yang menjual ikan, hewan laut dan berbagai hewan lain. Pada 10 Januari 2020 penyebabnya mulai teridentifikasi dan didapatkan kode genetiknya yaitu virus corona baru. Pada awalnya data epidemiologi menunjukkan $66 \%$ pasien berkaitan atau terpajan dengan pasar Seafood atau live market di Wuhan, provinsi Hubei, Tiongkok. Sampel isolate dari pasien diteliti dengan hasil menunjukkan adanya infeksi Coronavirus, jenis Betacoronavirus tipe baru, diberi nama 2019 novel Coronavirus (2019-nCoV). WHO memberi nama virus baru tersebut Severe Acute Respiratory Syndrome Coronavirus-2 (SARS-CoV-2) dan nama penyakitnya sebagai Coronavirus Disease 2019 (Covid-19) [3].

\subsection{Sensor IMU (Inertial Meansurnment Unit)}

Inertial Measurement Unit (IMU) merupakan suatu unit dalam modul elektronik yang mengumpulkan data percepatan angular dan akselerasi linear, yang kemudian dikirim ke unit pemroses utama. IMU terdiri dari Accelerometer (sensor percepatan) dan Gyroscope (sensor angular). Keduanya dapat digunakan untuk menjejaki keberadaan dan pergerakan suatu benda. Accelerometer digunakan untuk mengukur percepatan 
suatu benda dan Gyroscope digunakan untuk mengukur rotasi dari suatu benda [4]. Modul IMU 10 DOF (GY-87) dapat dilihat pada gambar 1.

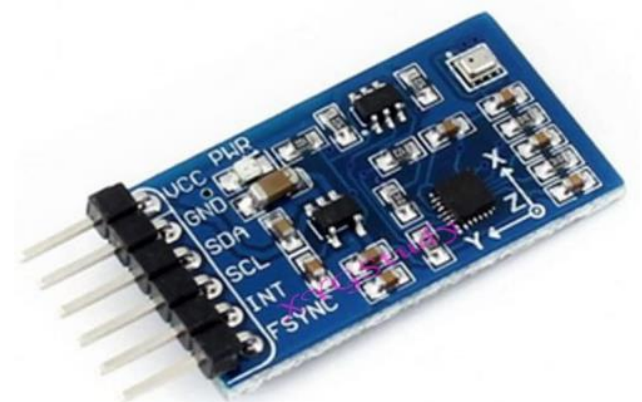

\section{Gambar 1. Sensor IMU (Inertial Measurement Unit) [5]}

\subsection{Mikrokontroler}

Secara umum mikrokontroller adalah sebuah sistem computer mini yang di dalamnya telah terdapat prosesor, RAM, dan ROM serta interface IO untuk berhubungan dengan dunia luar. Mikrokontroller memiliki fungsi utama yaitu sebagai pusat sistem kendali yang dapat diatur sesuai dengan keinginan pengguna. Pengaturan tersebut dilakukan melalui algoritma yang ditanamkan pada mikrokontroler tersebut. Saat ini, mikrokontroler telah mengalami kemajuan pesat, dahulu fitur mikrokontroler hanya sebatas pada IO, tetapi kini mikrokontroler jenis AVR telah memiliki fasilitas yaitu sistem mikrokontroler RISC (Reduce Instruction Set Computing), memiliki flash ROM, ADC internal, Timer, PWM jalur komunikasi serial, SPI, dan I2C. Mikrokontroller yang digunakan pada penelitian ini adalah Arduino Nano. Mikrokontroler Arduino Nano ditunjukkan pada Gambar 2.

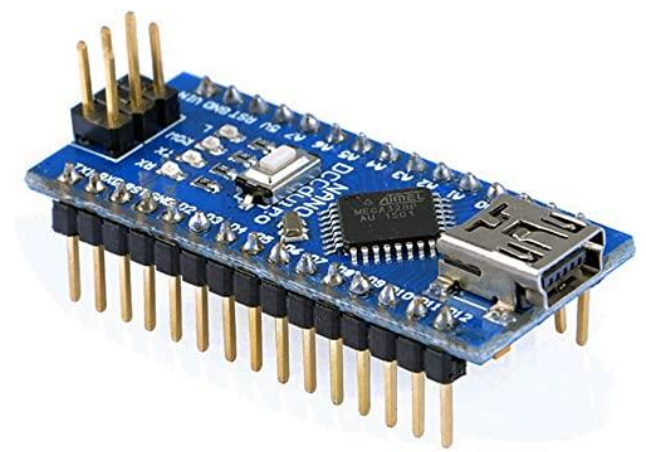

Gambar 2. Arduino Nano [6]

\subsection{Bluetooth HC-05}

Modul Bluetooth yang digunakan sebagai antarmuka nirkabel pada pembuatan ini adalah HC-05. Modul HC-05 adalah sebuah modul Bluetooth SPP (Serial Port Protocol) yang mudah digunakan untuk komunikasi serial Wireless (nirkabel) yang mengkonversi port serial ke Bluetooth. HC-05 menggunakan modulasi Bluetooth V2.0 + EDR (Enchanced Data Rate) 3 Mbps dengan memanfaatkan gelombang radio berfrekuensi 2,4 Ghz. Modul ini dapat digunakan sebagai mode slave maupun mode master. HC-05 dapat bekerja dengan 2 mode konfigurasi yaitu mode Setting (modul bekerja dalam mode respon perintah) dan mode komunikasi (modul bekerja dalam mode koneksi otomatis) [7]. Modul Bluetooth HC-05 ditunjukkan pada Gambar 3. 


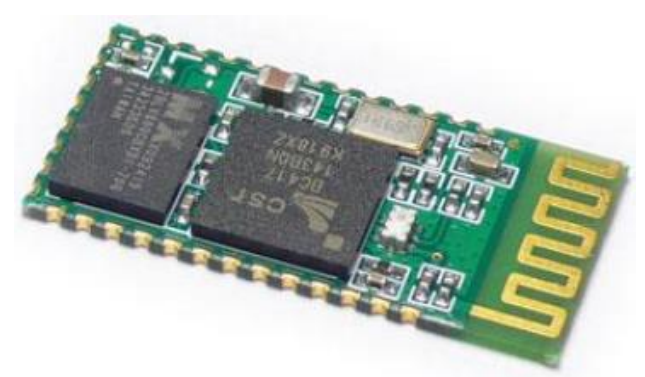

Gambar 3. Bluetooth HC-05 [8]

\subsection{Perancangan Perangkat Keras (Hardware)}

Perancangan perangkat keras (Hardware) terdiri dari baterai, regulator, sensor IMU, mikrokontroler, Bluetooth HC-05, dan smartphone. Pada perancangan perangkat keras baterai berfungsi sebagai penyedia arus listrik pada peralatan elektronik. Regulator berfungsi sebagai mengatur besar arus listrik yang masuk pada peralatan elektronik. Sensor IMU berfungsi sebagai sensor yang digunakan untuk mengukur kecepatan, orientasi dan gaya gravitasi dengan menggunakan sensor Accelerometer dan Gyroscope. Mikrokontroller berfungsi sebagai sebagai pengontrol rangkaian elektronik dan umunya dapat menyimpan program, dan terdiri dari CPU (Central Processing Unit), memori, I/O tertentu dan unit pendukung seperti Analog to Digital Converter $(A D C)$ dan lain-lain. Bluetooth HC-05 berfungsi sebagai komunikasi serial Wireless (nirkabel) yang mengkonversi port serial ke Bluetooth. Smarphone berfungsi sebagai menampilkan hasil pembacaan sensor IMU berupa accelerometer dan gyroscope. Blok diagram sistem secara keseluruhan ditunjukkan pada Gambar 4.

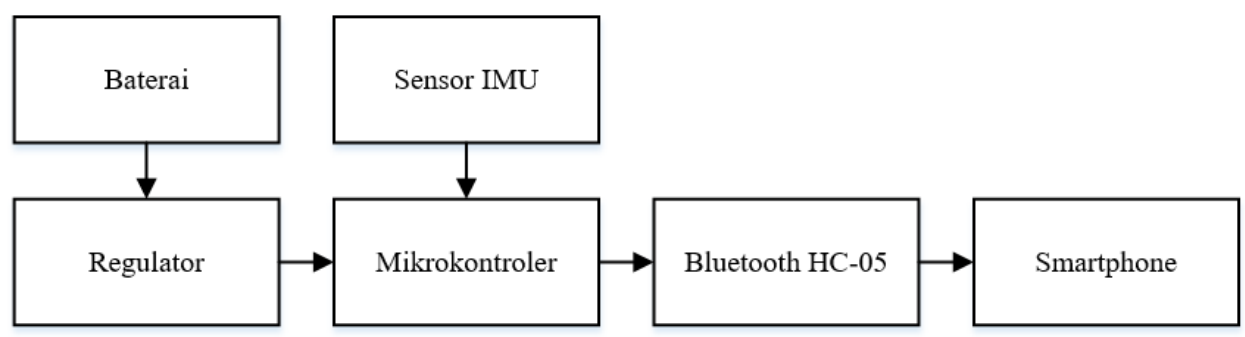

Gambar 4. Blok Diagram Sistem Secara Keseluruhan

\subsection{Perancangan Perangkat Lunak (Software)}

Perancangan perangkat lunak (Software) yang dugunakan menggunakan Bahasa pemrograman $\mathrm{C}$. Bahasa $\mathrm{C}$ sendiri merupakan bahasa tingkat tinggi yang sangat populer dan banyak digunakan oleh para programmer. Arduino IDE merupakan bahasa pemrograman yang sudah cukup lengkap library dan terdapat modul yang siap pakai atau shield yang bisa langsung dipasang pada board Arduino. Pemrograman harus memiliki tahap-tahap agar keluaran (output) yang diinginkan sesuai. Inisialisasi awal berfungsi untuk pemberian nilai awal yang dilakukan saat deklarasi variable atau obyek. Proses perubahan posisi dan percepatan sudut terjadi ketika sensor IMU melakukan perubahan posisi. Saat terjadi perubahan posisi dan percepatan sudut maka akan menampilkan informasi pada smartphone. Flowchart sistem secara keseluruhan ditunjukkan pada Gambar 5. 


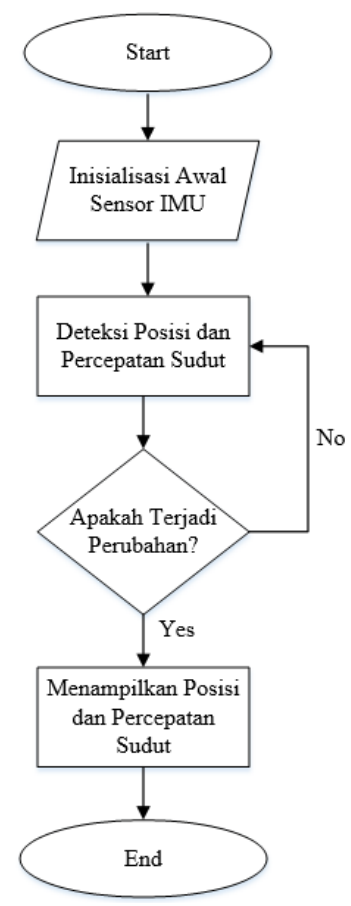

Gambar 5. Flowchart Sistem Secara Keseluruhan

\section{HASIL DAN PEMBAHASAN}

Pengujian sistem secara keseluruhan dapat Sistem komunikasi antara sensor IMU dan smartphone menggunakan Bluetooth HC-05. Data hasil pengujian Accelerometer dan Gyroscope dapat ditampilkan pada smartphone. Pengujian komunikasi nirkabel Bluetooth HC-05 dengan smartphone jarak maksimal yaitu 10 meter. Pengujian sensor IMU menggunakan smartphone dapat berjalan dengan baik. Pengujian sensor IMU menggunakan smartphone ditunjukkan pada Gambar 6.

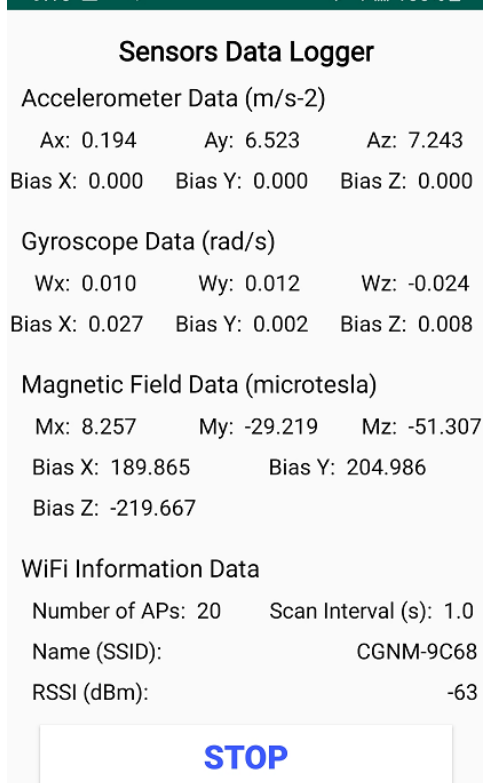

Gambar 6. Pengujian Sensor IMU Menggunakan Smartphone 


\section{KESIMPULAN}

Telah dibuat dan dirancang aplikasi Location Based Service untuk informasi dan pencarian lokal pasien Covid-19 berbasis sensor IMU. Sensor IMU berfungsi untuk mengukur kecepatan, orientsi dan gaya gravitasi menggunakan sensor Accelerometer dan Gyroscope. Pengujian komunikasi nirkabel menggunakan modul Bluetooth $\mathrm{HC}$-O5 jarak maksimal 10 meter. Pengujian sensor IMU menggunakan smartphone dapat berjalan dengan baik.

\section{DAFTAR PUSTAKA}

[1] P. D. O. Davies, "Multi-drug resistant tuberculosis," CPD Infect., vol. 3, no. 1, pp. 9-12, 2002.

[2] M. Firmansyah, "Rancang bangun sistem fall detection untuk orang lanjut usia berbasis Inertial Measurement Unit," TEKTRIKA - J. Penelit. dan Pengemb. Telekomun. Kendali, Komputer, Elektr. dan Elektron., vol. 1, no. 2, pp. 133-137, 2019.

[3] M. M. C. Otálora, "Yuliana," Parq. los afectos. Jóvenes que cuentan, vol. 2, no. February, pp. 124-137, 2020.

[4] R. Patmasari and S. Saidah, "Implementasi dan analisis Kalman Filter pada sensor Inertial Measurement Unit (IMU); Implementation and analysis of Filter Kalman on sensor Inertial Measurement Unit (IMU)," pp. 1-9.

[5] WaveShare, "10 DOF IMU sensor user manual," 10 DOF IMU Sens. User Man., no. C, pp. 1-6, 2000.

[6] Arduino LLC et al., "Arduino nano," vol. 2010, no. semnasIF, p. 1, 2012.

[7] D. K. Ilmiah et al., "Rancang bangun sistem komunikasi data game controller menggunakan bluetooth pada robot humanoid soccer," pp. 5-6, 2012.

[8] ITead Studio, "HC-05 bluetooth module," Datasheet, p. 1, 2010. 